Universidad
de Alcalá

BIBLIOTECA

Document downloaded from the institutional repository of the University of Alcala: http://dspace.uah.es/dspace/

This is a peer reviewed version of the following article:

Meli, P., Martínez-Ramos, M. \& Rey-Benayas, J. 2013, "Selecting Species for Passive and Active Riparian Restoration in Southern

Mexico", Restoration Ecology, vol. 21, no. 2, pp. 163-165.

Which has been published in final form at http://dx.doi.org/10.1111/i.1526-100X.2012.00934.x

This article may be used for non-commercial purposes in accordance with Wiley Terms and Conditions for Use of Self-Archived Versions.

(C) 2013 Wiley
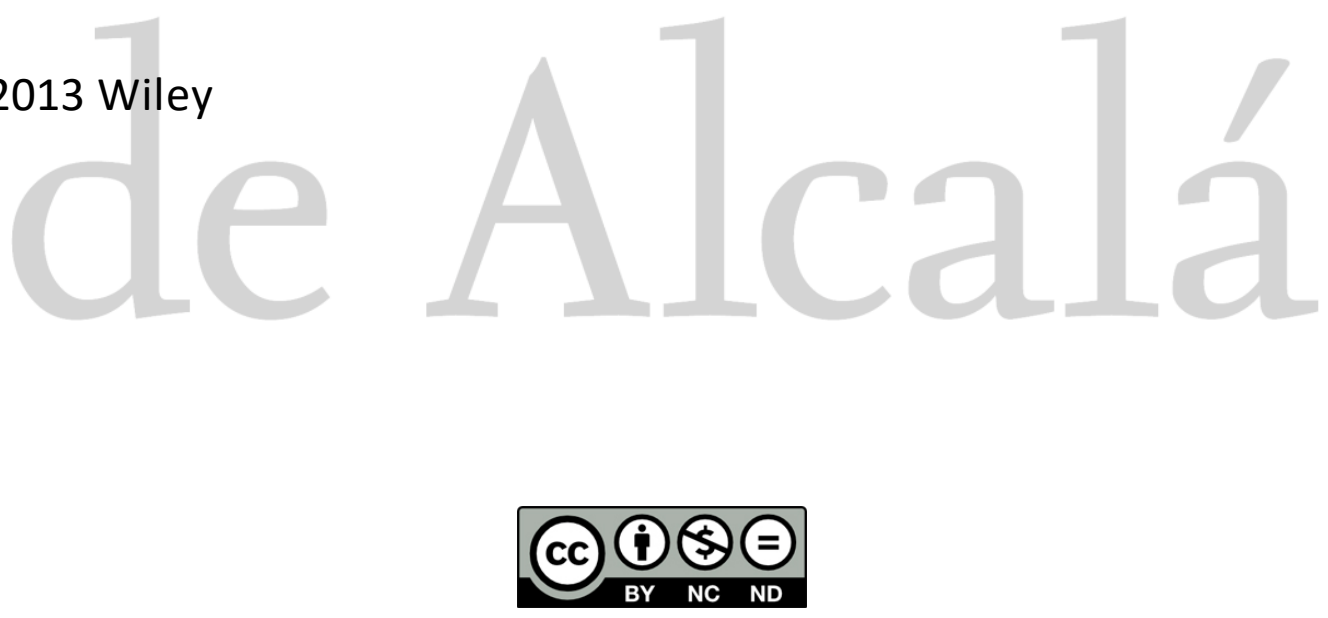

This work is licensed under a

Creative Commons Attribution-NonCommercial-NoDerivatives

4.0 International License. 
Restoration

Ecology

\section{Selecting species for passive and active riparian restoration} in Southern Mexico.

\begin{tabular}{|r|l|}
\hline Journal: & Restoration Ecology \\
\hline Manuscript ID: & REC-12-174.R2 \\
\hline Manuscript Type: & Short Communication \\
\hline Date Submitted by the Author: & n/a \\
\hline Complete List of Authors: & $\begin{array}{l}\text { Meli, Paula; Natura y Ecosistemas Mexicanos A.C., } \\
\text { Cartínez-Ramos, Miguel; U.N.A.M., Centro de Investigaciones en } \\
\text { Cosistemas } \\
\text { Rey Benayas, Jose Maria; Universidad de Alcala, Ecologia }\end{array}$ \\
\hline Keywords: & indicators, Lacandonia, natural regeneration, rainforest, recovery \\
\hline &
\end{tabular}

\section{SCHOLARONE ${ }^{\text {m }}$}

Manuscripts 
1 Selecting species for passive and active riparian restoration in Southern Mexico

2 Paula Meli ${ }^{1,3}$, Miguel Martínez-Ramos ${ }^{2}$ and José M. Rey-Benayas ${ }^{3}$

$3{ }^{1}$ Natura y Ecosistemas Mexicanos A.C., San Jacinto 23-D, Col. San Ángel, México D.F., CP

$4 \quad 01000$, México.

$5{ }^{2}$ Centro de Investigaciones en Ecosistemas, Universidad Nacional Autónoma de México,

6 Antigua Carretera a Pátzcuaro No. 8701, CP 58190, Morelia, México.

$7 \quad{ }^{3}$ Universidad de Alcalá, Edificio de Ciencias, Departamento de Ecología, 28871, Alcalá de

8 Henares, Madrid, Spain.

9 Author for correspondence: P. Meli, email paula@naturamexicana.org.mx

10 Running title: Selecting species for riparian restoration.

11 Type of article: Short communication.

12 Key words: indicators, Lacandonia, natural regeneration, rainforest, recovery.

13245 words in the abstract

142,167 words in the manuscript

151,499 words in the main text

1611 references

$17 \quad 1$ Table 


\section{Abstract}

2 In revegetation projects, distinguishing species that can be passively restored by natural

3 regeneration from those requiring active restoration is not a trivial decision. We quantified

4 dominance of tree species (measured by an Importance Value Index, $\mathrm{IVI}_{\mathrm{i}}$ ) and used abundance-

5 size correlations to select those species suitable for passive and/or active restoration of disturbed

6 riparian vegetation in the Lacandonia region, Southern Mexico. We sampled riparian vegetation

7 in a $50 \times 10 \mathrm{~m}$ transect in each of six reference $(\mathrm{RE})$ and five disturbed (DE) riparian

8 ecosystems. The species accumulating more than $50 \%$ of total IVI in each ecosystem were

9 selected and Spearman rank correlation between abundance and diameter classes was calculated.

10 For eight species passive restoration should be sufficient for their establishment. Other eight

11 species necessarily should be transplanted by means of active restoration. Four species

12 regenerate well in only one ecosystem type, so both restoration strategies could be used

13 depending on the particular project context. Finally, three species were not important in the RE

14 and were not selected at this first stage of our restoration project. The high number of tree

15 species found in the RE suggests that the pool of species for ecological restoration is wide.

16 However, sampling in both ecosystem types helped us to reduce the number of species that will

17 require active restoration. Restoration objectives must guide the methods to implement, and

18 perhaps in different conditions other criteria such as the dispersal syndrome or the social value

19 could be considered in the selection of species.

20 Key words: indicators, Lacandonia, natural regeneration, rainforest, recovery.

22 Introduction

23 An aim of ecological restoration is to reestablish in a degraded or destroyed ecosystem the

24 characteristic species assemblage and appropriate community structure occurring in the

25 reference ecosystem (SER 2004). Many tropical and humid temperate ecosystems can recover 
1 with little or no human intervention when the soil has not been severely degraded (González-

2 Espinosa et al. 2007). In these cases, "cessation of activities that are causing degradation or

3 preventing recovery" (passive restoration, Kauffman et al. 1997) is enough to drive ecosystem

4 recovery, and it can be considered the first step in ecological restoration (Rey-Benayas et al.

5 2008). However, although passive restoration may be sometimes sufficient for some species,

6 others need active restoration. Revegetation -the deliberated introduction of native species- is

7 one of the tools most frequently used in ecological restoration, but it is usually time and

8 economically consuming. Therefore, distinguishing species that can be passively restored by

9 natural regeneration from those species requiring active restoration can greatly reduce the cost

10 and effort of a restoration project. However, making this determination is not trivial. Our main

11 goal is selecting species for passive and active restoration of riparian vegetation in the

12 Lacandonia region, Southern Mexico in the early stage of this restoration project.

15 The study was conducted in Marqués de Comillas Municipality $\left(16 \circ 54^{\mathrm{L}} \mathrm{N}, 92 \circ 05^{\mathrm{L}} \mathrm{W}\right)$, in the

16 Lacandonia region, Southern Mexico. Mean annual precipitation is about 3,000 $\mathrm{mm}$ and a short

17 dry season $\left(<100 \mathrm{~mm} \mathrm{month}^{-1}\right)$ occurs between January and April (Martínez-Ramos et al.

18 2009). Humans settled this region during the early 1970s and former rainforest has been

19 extensively converted to agricultural fields (De Jong et al. 2000).

20 Our reference ecosystem (RE) consisted in six pristine riparian areas. Our disturbed

21 ecosystem (DE) includes five areas that were completely deforested and later abandoned (3 to

22 10-year-old). Presently DE areas are covered by secondary riparian vegetation. In each study

23 area we sampled riparian vegetation in a $50 \times 10 \mathrm{~m}$ transect, where we measured the height and

24 diameter at breast height $(\mathrm{dbh})$ of all trees with $\mathrm{dbh}>1.5 \mathrm{~cm}$. The dbh data was converted to

25 basal area values using $\pi *\left(\mathrm{dbh}^{*} 0.5\right)$. For each transect and species, we calculated an Importance 
1 Value Index $\left(\mathrm{IVI}_{\mathrm{i}}\right)$ as the sum of the species relative density, relative frequency and relative

2 basal area divided by three (Curtis \& McIntosh 1951). Our analysis was restricted to those

3 species with the greatest $\mathrm{IVI}_{\mathrm{i}}$ and that together covered more than $50 \%$ of total IVI in each

4 ecosystem. Per transect we calculated for each species their abundance $\left(\mathrm{N}_{\mathrm{i}}\right.$, number of stems of

5 species i per transect) in each of ten dbh classes (every $5 \mathrm{~cm}$ each). Then, for each transect and

6 species, we calculated the correlation (Spearman rank correlation, $r_{s}$ ) between abundance $[\log$

$7 \quad(\mathrm{Ni}+1)]$ and the mid-point of the dbh classes (hereafter called abundance-size correlation). A

8 high regeneration potential is represented by a diminishing number of individuals as diameter

9 sizes enlarges. This trend will result in a high and negative correlation (high availability of small

10 sized trees), and therefore an acceptable potential for passive establishment of the species. A

11 positive or non-significant correlation (lack of small sized trees) means that the species does not

12 establish naturally and therefore it needs to be actively restored.

14 Results

15 A total of 115 species were found in RE, while a total of 97 species were found in DE. The first

16 fifteen species accounted for $54 \%$ and $51 \%$ of the total IVI in the RE and DE, respectively.

17 From these species, five species were common to RE and DE (A. leucocalyx, A. hottlei, C.

18 schiedeanus, D. guianense, and Ficus sp.), and two were absent in the RE. We therefore

19 characterized 23 species for assessment of restoration (Table 1).

20 Eight species showed significant and negative abundance-size correlation $\left(\mathrm{r}_{\mathrm{s}}<-0.6, p<\right.$

210.05 ) in both ecosystem types suggesting that passive restoration could be sufficient for their

22 successful establishment (Table 1). At the other extreme, eight species were either absent in DE

23 or the abundance-size correlation was not significant and thus such species should be introduced

24 by active restoration. Four species regenerate well in only one ecosystem type, so either strategy

25 could be used depending on the particular project context. Finally, the three species that were 
1 not included in the first fifteen species with high $\mathrm{IVI}_{\mathrm{i}}$ in $\mathrm{RE}$ were not selected for restoration

2 (but they can be used, for example, for nursery propagation).

3

\section{Discussion}

5 The interpretation of the $\mathrm{IVI}_{\mathrm{i}}$ and the abundance-size correlations allowed us reaching a

6 preliminary list of 20 species with potential use for the restoration of riparian vegetation in

7 Lacandonia and provide recommendations on possible restoration strategies for particular

8 species. The high number of tree species found in RE shows that the pool of species for

9 ecological restoration is wide and sampling in both ecosystem types helped us to develop a

10 comprehensive list of species based on their abundance and size. However, the predictive

11 potential of the abundance-size correlations could be limited by the small sample sizes. Low

12 species abundances in highly diverse humid tropics difficult to perform accurate correlations

13 without more data. Furthermore, the predictive capacity of the abundance-size correlations could

14 decrease as the age of DE increases and its species composition starts to resemble that of the 15 RE.

Our method did not target some pioneer species (S. parahybum, Piper sp.) because their

17 ability to establish naturally in degraded areas. Such pioneer species may not be the most

suitable species in economic terms when degradation is not very severe, as in our study. Where

land degradation is severe, as in degradation caused by mining (Sharma \& Sunderraj 2005), or

with specific problems such as high erosion on steep slopes (dos Santos et al. 2008), the use of

21 pioneer species adapted to grow on disturbed or degraded ecosystems could be recommended

22 for active restoration.

We concluded that our method is useful to select species for restoration due to its relative

24 low cost and ease that makes it accessible to different stakeholders. It could be applied in other 
1 ecosystems where trees are dominant, but its use would be limited in grasslands or other

2 ecosystems where species regeneration is difficult to estimate. Finally, as in any restoration

3 project, the method selected will depend on the main objectives. In different conditions other

4 criteria could be considered in the selection of species, including adaptive capacity for different

5 soils (Sharma \& Sunderraj 2005), social values (cf. Moreno-Cassasola \& Paradowska 2009),

6 and attributes such as dispersal syndromes (Sansevero et al. 2009). Rare species such shrubs and

7 herbaceous species are also important, but not necessarily at early stages of restoration.

8

9 Implications for Practice

10

11

12

\section{$22 \quad$ Literature cited}

\section{Acknowledgements} Government).

- At early stages of restoration of ecosystems dominated by trees, the combination of species dominance indexes (e.g. $\mathrm{IVI}_{\mathrm{i}}$ ) and abundance-size correlations could be used to select a preliminary list of species suitable for passive or active restoration.

- Species that establish by natural regeneration could be used in passive restoration actions when ecosystems are not severely degraded.

Funding was provided by a Rufford Small Grant for Nature Conservation to PM (40.11.09), and by Pemex and the WWF-FCS Alliance to Natura. JMRB thanks to Projects CGL2010-18312 (Spanish Ministry of Science and Education) and S2009AMB-1783 REMEDINAL-2 (Madrid 
1 Curtis, J. T, and R. P. McIntosh. 1951. An upland forest continuum in the prairie-forest border

2

3 De Jong, B. H. J., S. Ochoa-Gaona, M. A. Castillo-Santiago, N. Ramírez-Marcial, and M. A.

4

Cairns. 2000. Carbon flux and patterns of land-use / land-cover change in the Selva Lacandona, Mexico. Ambio 29:504-511.

Dos Santos, R., V. Citadini-Zanette, L. S. Leal-Filho, and W. T. Hennies. 2008. Spontaneous Vegetation on Overburden Piles in the Coal Basin of Santa Catarina, Brazil. Restoration Ecology 16:444-452.

González-Espinosa, M., N. Ramírez-Marcial, A. Camacho-Cruz, S. Holz, J. M. Rey-Benayas, and M. R. Parra-Vázquez. 2007. Restauración de bosques en territorios indígenas de Chiapas: Modelos ecológicos y estrategias de acción. Boletín de la Sociedad Botánica de México 80:11-23.

Kaufmann, J. B., R. I. Beschta, N. Otting, and D. Lytjen. 1997. An ecological perspective of riparian and stream restoration in the western United States. Fisheries 22:12-24.

Martínez-Ramos, M., N. P. R. Anten, and D. Ackerly. 2009. Defoliation and ENSO effects on vital rates of a neotropical understorey palm. Journal of Ecology 97:1050-1061.

Moreno-Cassasola, P., and K. Pardowska. 2009. Useful plants of tropical dry forest on the coastal dunes of the center of Veracruz State. Madera y Bosques 15:21-44.

Rey-Benayas, J. M., J. M. Bullock, and A. C. Newton. 2008. Creating woodland islets to reconcile ecological restoration, conservation, and agricultural land use. Frontiers in Ecology and Environment 6:329-336.

Sansevero, J.B.B., P. V. Prieto, L. F. Duarte de Moraes, and P. J. F. Pena-Rodrigues. 2009. Natural regeneration in plantations of native trees in lowland Brazilian Atlantic forest: 
1 community structure, diversity, and dispersal syndromes. Restoration Ecology 19:379-

2389.

3 Sharma, D., and S. F. W. Sunderraj. 2005. Species selection for improving disturbed habitats in $4 \quad$ Western India. Current Science 88:462-467.

5 Society for Ecological Restoration International Science \& Policy Working Group (SER) 2004.

6 The SER International Primer on Ecological Restoration. www.ser.org \& Tucson:

$7 \quad$ Society for Ecological Restoration International. 
1 Table 1. Species Importance Value Index (IVI) and Spearman rank correlation coefficient $\left(\mathrm{r}_{\mathrm{s}}\right)$ in reference and disturbed riparian

2 ecosystems of 23 native tree species found in the Lacandonia region, and recommendation for restoration (passive, active, or non-

3 selected -NS- species for restoration).

\begin{tabular}{|c|c|c|c|c|c|c|c|c|}
\hline \multirow[b]{2}{*}{ Species } & \multirow[b]{2}{*}{ Family } & \multicolumn{3}{|c|}{ Reference ecosystem } & \multicolumn{3}{|c|}{ Disturbed ecosystem } & \multirow[b]{2}{*}{$\begin{array}{l}\text { Restoration } \\
\text { recommendation }\end{array}$} \\
\hline & & IVI & $\mathbf{r}_{\mathrm{s}}$ & $p$ & IVI & $\mathbf{r}_{\mathrm{s}}$ & $p$ & \\
\hline Ficus sp. & Moreaceae & 10.145 & 0.5 & 0.1173 & 2.212 & -0.1 & 0.7699 & active \\
\hline Cojoba arbórea & Mimosoideae & 6.264 & -0.2089 & 0.5376 & 0.504 & -0.4 & 0.2229 & active \\
\hline Dialium guianense & Caesalpinoideae & 5.305 & -0.485 & 0.1305 & 5.018 & 0.051 & 0.8817 & active \\
\hline Protium sp. & Burseraceae & 4.781 & -0.7862 & 0.0041 & 2.365 & -0.7862 & 0.0041 & passive \\
\hline Ampelocera hottleii & Ulmaceae & 4.394 & -0.5625 & 0.0717 & 1.233 & -0.7747 & 0.0051 & passive \\
\hline Brosimum alicastrum & Moreaceae & 3.494 & -0.2293 & 0.4975 & 0.485 & -0.5 & 0.1173 & active \\
\hline Brosimum costarricanum & Moreaceae & 2.854 & -0.2132 & 0.5291 & . & . & . & active \\
\hline Guarea glabra & Meliaceae & 2.851 & -0.6742 & 0.0229 & 0.356 & -0.7659 & 0.006 & passive \\
\hline Croton schiedeanus & Euphorbiaceae & 2.316 & -0.7551 & 0.0072 & 5.039 & -0.917 & $<.0001$ & passive \\
\hline Pouteria durlandii & Sapotaceae & 2.305 & -0.887 & 0.0003 & 1.201 & -0.6068 & 0.0478 & passive \\
\hline
\end{tabular}




\begin{tabular}{|c|c|c|c|c|c|c|c|c|}
\hline Calophyllum brasiliense & Clusiaceae & 1.995 & -0.4842 & 0.1313 & 0.622 & -0.5 & 0.1173 & active \\
\hline Nectandra sleneri & Lauraceae & 1.898 & -0.7862 & 0.0041 & . & . & . & active \\
\hline Albizia leucocalyx & Mimosoideae & 1.892 & -0.8522 & 0.0009 & 4.223 & -0.2582 & 0.4433 & passive / active \\
\hline Vochysia guatemalensis & Vochysiaceae & 1.864 & -0.1195 & 0.7263 & 2.004 & -0.3772 & 0.2528 & active \\
\hline Eugenia mexicana & Myrtaceae & 1.777 & -0.8291 & 0.0016 & 0.831 & -0.5 & 0.1173 & passive / active \\
\hline Castilla elastica & Moreaceae & 1.554 & -0.7974 & 0.0033 & 3.648 & -0.7862 & 0.0041 & passive \\
\hline Spondias mombin & Anacardiaceae & 0.885 & -0.5164 & 0.1039 & 3.235 & -0.8449 & 0.0011 & passive \\
\hline Inga vera & Mimosoideae & 0.859 & -0.8315 & 0.0015 & 3.896 & -0.6116 & 0.0456 & passive \\
\hline Lonchocarpus guatemalensis & Papilionoideae & 0.725 & -0.7659 & 0.006 & 2.956 & -0.5745 & 0.0645 & NS \\
\hline Cecropia peltata & Cecropiaceae & 0.635 & -0.7946 & 0.0035 & 4.779 & -0.8318 & 0.0015 & passive \\
\hline Orthion subsessile & Violaceae & 0.548 & -0.6607 & 0.0269 & 2.068 & -0.7833 & 0.0043 & passive \\
\hline Piper sp. & Piperaceae & 0.278 & -0.5 & 0.1173 & 2.275 & -0.7862 & 0.0041 & NS \\
\hline Schizolobium parahybum & Caesalpinoideae & 0.117 & -0.1 & 0.7699 & 4.306 & -0.8102 & 0.0025 & NS \\
\hline
\end{tabular}

